\title{
Artikel
}

\section{Een verbod op wraakporno}

\author{
Het nieuwe artikel 139h Sr kritisch beschouwd
}

Mr. M. (Michael) Berndsen*

\section{Achtergrond van de strafbaarstelling}

Het begon allemaal als een grap. Een jongen deed zich via social media voor als meisje en wist zo de veertienjarige Önur uit Enschede te verleiden tot het sturen van een naaktselfie. Die foto werd verspreid via social media en kwam zo bij alle contacten van Önur terecht. Deze schande viel de veertienjarige jongen zwaar. Een dag later nam Önur afscheid van zijn vriendin en maakte hij een einde aan zijn leven. ${ }^{1}$

Een ander voorbeeld is het wraakpornonetwerk waar techjournalist Daniël Verlaan undercover ging. Hij ontdekte in 2018 dat duizenden personen seksueel beeldmateriaal van jonge vrouwen uitwisselden in een gedeelde map in de cloud. $^{2}$

De massale aanwezigheid van camera's in telefoons, laptops en tablets en de mogelijkheid om beelden in één klik via internet te delen, maakt het gemakkelijker dan ooit tevoren om pikant beeldmateriaal uit te wisselen. De keerzijde daarvan is dat zulk beeldmateriaal ook tegen de wil van betrokkenen kan worden gemaakt en verspreid, zoals de twee genoemde voorbeelden illustreren. Deze vormen van misbruik van seksueel beeld- materiaal worden - enigszins ongelukkig, want er is lang niet altijd sprake van een wraakmotief - ook wel mraakporno genoemd.

In 2014 werden Kamervragen gesteld over de wenselijkheid van strafbaarstelling van wraakporno, nadat in de media berichten waren verschenen dat Japan als eerste land ter wereld dergelijke wetgeving had geintroduceerd. Toenmalig minister Opstelten (Veiligheid en Justitie) antwoordde dat 'de Nederlandse wetgeving op dit moment in beginsel geen lacunes [bevat] om op te kunnen treden tegen het ongewenst verspreiden van seksueel getinte beelden'. ${ }^{3}$ Aanpassing van de wetgeving werd door de minister dus niet nodig geacht.

Toch kondigde zijn opvolger Van der Steur begin 2016 in een Kamerbrief aan dat de bescherming tegen 'digitale ontucht' zou worden verruimd. ${ }^{4}$ In 2017 werd in het regeerakkoord van het kabinet-Rutte III opgenomen dat een zelfstandige strafbaarstelling voor 'het verspreiden van wraakporno' zou worden ingevoerd. ${ }^{5}$ Dit was volgens het kabinet noodzakelijk omdat verspreiding van wraakporno diep ingrijpt in de persoonlijke levenssfeer van de afgebeelde persoon.

\section{Parlementaire behandeling}

Bij de behandeling van het aangekondigde wetsvoorstel werd angevoerd dat het antal meldingen van misbruik
* Mr. M. Berndsen is advocaat bij Meijers Canatan Advocaten te Amsterdam en is onder meer gespecialiseerd in cybercrime en cassatie.

1. P. de Graaf, 'Tieners toch vervolgd na dood Önur', de Volkskrant 15 december 2018, p. 13.

2. A. Kranenberg \& L. Reijmer, 'De mannen die online naaktfoto's ruilen', de Volkskrant 14 juli 2018, p. 8-11.
3. Aanhangsel Handelingen I/ 2014/15, 933, p. 3 (antwoord minister Opstelten op Kamervragen van de PvdA).

4. Kamerstukken I/ 2015/16, 29279, nr. 300, p. 9.

5. 'Vertrouwen in de toekomst'. Regeerakkoord 2017-2021 (VVD, CDA, D66 en ChristenUnie), 10 oktober 2017, p. 6. 
van seksueel beeldmateriaal sterk toenam. ${ }^{6}$ Toch waren niet alle ketenpartners en fracties direct overtuigd van de noodzaak van nieuwe wetgeving. ${ }^{7}$ Verspreiders van wraakporno werden immers in voorkomende gevallen al vervolgd voor smaad, laster of belediging, terwijl ook het gebruik van een verborgen camera onder omstandigheden al strafbaar was. ${ }^{8}$ Minister Grapperhaus (Justitie en Veiligheid) was zich hiervan bewust, maar benadrukte dat de bestaande strafbepalingen 'de lading nog onvoldoende dekten'. ${ }^{9}$ Het voorgestelde artikel $139 \mathrm{~h} \mathrm{Sr}$ zou bijdragen aan 'een eenduidige strafrechtelijke aanpak' en bovendien zorgen voor 'herkenbare erkenning van leed dat slachtoffers wordt aangedaan'. Daarnaast zou van de specifieke strafbaarstelling het signaal uitgaan dat dit type gedrag ernstig wordt afgekeurd. ${ }^{10}$ Later antwoordde de minister nog dat de nieuwe strafbepaling opsporing, vervolging en bewezenverklaring van deze delicten gemakkelijker zou maken, terwijl het bereik van de voorgestelde bepaling ook ruimer zou zijn. Zo wees de minister op het verschijnsel van voyeurs die ongewenst filmen onder iemands rok, terwijl de bestaande bepalingen in die situatie niet altijd tot succesvolle vervolging konden leiden. ${ }^{11}$

Ook was er kritiek op de vorm van de voorgestelde strafbepaling. Zo concludeerde het College van ProcureursGeneraal tijdens de consultatieronde dat 'het voorgestelde artikel $139 \mathrm{~h}$ in zijn huidige vorm voor de praktijk niet werkbaar is'. ${ }^{12}$ Met name de omschrijving van het seksuele materiaal leidde tot kritiek vanuit diverse hoeken. ${ }^{13}$ Waar de consultatieversie nog repte van 'seksueel beeldmateriaal', werd in het wetsvoorstel gekozen voor 'afbeelding van seksuele aard'. ${ }^{14}$ Dat de reikwijdte van de strafbaarstelling nog steeds niet uitblinkt in helderheid, zal hierna nog blijken bij de bespreking van de strafbepaling en de knelpunten daarvan.

Het oorspronkelijke wetsvoorstel kende in het tweede lid de zwaarste opzetvariant, namelijk de eis van 'oogmerk van benadeling van de betrokkene'. Alleen dan zou

6. Kamerstukken I/ 2018/19, 35080, nr. 3 (MvT), p. 3.

7. Zo vroeg de VVD de minister welk gedrag nu, in tegenstelling tot voorheen, wel strafbaar zou worden (Kamerstukken I/ 2018/19, 35080, nr. 5 (verslag), p. 5).

8. Zie bijvoorbeeld Hof Amsterdam 19 oktober 2017, ECLI:NL:GHAMS: 2017:4648

9. Kamerstukken // 2018/19, 35080, nr. 3 (MvT), p. 4. In de literatuur wijst Goudsmit op een ander, normatief argument voor aparte strafbaarstelling in plaats van het gebruik van smaad en laster. Immers veronderstellen smaad en laster dat het slachtoffer ergens van wordt beschuldigd, hetgeen impliceert dat het slachtoffer niet juist heeft gehandeld. Dit is een vorm van victim blaming en miskent bovendien dat privémateriaal als zodanig niet verkeerd is. M.L.R. Goudsmit, 'Criminalising image-based sexual abuse: an analysis of the Dutch bill against "revenge pornography"', AA 2019, p. 444

10. Idem.

11. Het verbod op heimelijk filmen in art. $139 \mathrm{f} \mathrm{Sr}$ geldt immers niet in voor het publiek toegankelijke plaatsen, terwijl art. 441b Sr vereist dat een camera ergens in of op is aangebracht (Kamerstukken I/ 2018/19, 35080, nr. 7 (nota n.a.v. het verslag), p. 7-8).

12. Advies OM d.d. 12 juni 2018, p. 6.

13. Advies NOvA d.d. 11 juni 2018, p. 9; Advies OM d.d. 12 juni 2018, p. 5-6.

14. Kamerstukken // 2018/19, 35080, nr. 7 (nota n.a.v. het verslag), p. 19. in plaats van één jaar een strafmaximum van twee jaar mogelijk zijn. Adviezen van de Nederlandse Vereniging voor Rechtspraak en de Raad voor de rechtspraak wezen de minister erop dat 'oogmerk' moeilijk te bewijzen is en in casu bovendien onnodig. ${ }^{15}$ Immers strekt het wetsvoorstel ertoe benadeling als zodanig te voorkomen, ook wanneer het oogmerk van de verspreider daar niet op was gericht. Omdat men vreesde dat een schuldige vrijuit zou kunnen gaan door bijvoorbeeld te verklaren dat hij slechts indruk wilde maken op zijn vrienden - en dus geen oogmerk van benadeling had - is de eis van oogmerk bij amendement gesneuveld. ${ }^{16}$ In de uiteindelijke wettekst hoeft degene die de afbeelding openbaar maakt slechts te 'weten' dat die openbaarmaking 'nadelig' kan zijn voor de afgebeelde persoon. Daarmee volstaat voorwaardelijk opzet op die mogelijke nadeligheid.

Het amendement bevatte nog een andere noemenswaardige wijziging. Op grond van het tweede lid kan ook de maximale gevangenisstraf van twee jaar worden opgelegd voor het verspreiden van een afbeelding van seksuele aard waarvan men weet of redelijkerwijs moet vermoeden dat deze heimelijk is gemaakt. Nadat dit amendement was aangenomen, werd het wetsvoorstel aangenomen.

\section{De nieuwe bepaling nader beschouwd}

3.1. Artikel $139 \mathrm{~h} \mathrm{Sr}$

Artikel 139h Sr is per 1 januari 2020 in werking getreden en luidt als volgt: ${ }^{17}$

1. Met gevangenisstraf van ten hoogste een jaar of geldboete van de vierde categorie wordt gestraft:

a. hij die opzettelijk en wederrechtelijk van een persoon een afbeelding van seksuele aard vervaardigt;

b. hij die de beschikking heeft over een afbeelding als bedoeld onder a terwijl hij weet of redelijkerwijs moet vermoeden dat deze door of als gevolg van een onder a strafbaar gestelde handeling is verkregen.

2. Met gevangenisstraf van ten hoogste twee jaren of geldboete van de vierde categorie wordt gestraft:

a. hij die een afbeelding als bedoeld in het eerste lid, onder a, openbaar maakt terwijl hij weet of redelijkerwijs moet vermoeden dat deze door of als gevolg van een in het eerste lid, onder a, strafbaar gestelde handeling is verkregen;

15. Advies NVvR d.d. 5 juli 2018, p. 2-3; Advies Raad voor de rechtspraak d.d. 13 juni 2018, p. 3.

16. Kamerstukken I/ 2018/19, 35080, nr. 21 (nader gewijzigd amendement van de leden Van Wijngaarden en Groothuizen ter vervanging van dat gedrukt onder nr. 14).

17. Stb. 2019, 421 (inwerkingtreding). Bekendmaking in Stb. 2019, 311 Wet van 27 september 2019 tot wijziging van onder meer het Wetboek van Strafrecht in verband met de herwaardering van de strafbaarstelling van enkele actuele delictsvormen (herwaardering strafbaarstelling actuele delictsvormen). 
b. hij die van een persoon een afbeelding van seksuele aard openbaar maakt, terwijl hij weet dat die openbaarmaking nadelig voor die persoon kan zijn.

Het eerste lid ziet op heimelijk gemaakt materiaal, zowel het vervaardigen van als het beschikking hebben over zulk beeldmateriaal. Het tweede lid stelt twee varianten van het openbaar maken van seksuele afbeeldingen strafbaar. Lid 2 sub a verbiedt het openbaar maken van materiaal waarvan men ten minste redelijkerwijs moet vermoeden dat het heimelijk is gemaakt. De variant onder lid 2 sub b verbiedt ook het openbaar maken van seksuele afbeeldingen die vrijmillig tot stand zijn gekomen, maar dan is wel vereist dat de openbaarmaker weet dat de openbaarmaking nadelig kan zijn voor de afgebeelde persoon.

Ondanks de strafmaxima van één jaar (eerste lid) en twee jaar gevangenisstraf (tweede lid) gelden alle varianten van de bepaling als feit waarvoor voorlopige hechtenis is toegelaten. Artikel $139 \mathrm{~h} \mathrm{Sr}$ is namelijk opgenomen in de opsomming van artikel 67 lid 2 sub b Sv. De wetgever achtte dit wenselijk zodat dwangmiddelen als aanhouden buiten heterdaad, inverzekeringstelling en voorlopige hechtenis en de inzet van bijzondere opsporingsbevoegdheden (bijvoorbeeld het vorderen van gegevens) kunnen worden toegepast.

Verder is noemenswaardig dat de bepaling in het Wetboek van Strafrecht is opgenomen in Boek II, Titel V, en dus geldt als een misdrijf tegen de openbare orde. Hiervoor is bewust gekozen omdat de bescherming van privacy deel uitmaakt van de bescherming van de openbare orde. ${ }^{18}$ Enigszins verrassend is dit wel, omdat de bepaling zich beperkt tot seksuele privacy. Het College van Procureurs-Generaal vond dit inconsequent en adviseerde om ofwel het woord 'seksueel' uit de delictsomschrijving te schrappen, ofwel de bepaling onder te brengen in de titel Misdrijven tegen de zeden. ${ }^{19}$ De minister hield echter voet bij stuk en overwoog dat het strafbaar stellen van iedere openbaarmaking van beeldmateriaal waardoor de afgebeelde 'in een compromitterende situatie wordt gebracht' dermate ruim zou zijn, dat deze op gespannen voet zou komen te staan met het legaliteitsbeginsel en de vrijheid van meningsuiting. ${ }^{20}$

\subsection{De bestanddelen}

Tot op heden zijn mij nog geen zaken bekend waarin artikel $139 \mathrm{~h} \mathrm{Sr}$ ten laste is gelegd. Wel kan uit de wetsgeschiedenis in zekere mate worden afgeleid welke invulling en afbakening van de bestanddelen de minister voor ogen heeft gehad.

Het centrale bestanddeel van artikel $139 \mathrm{~h} \mathrm{Sr}$ is 'een afbeelding van seksuele aard'. Het gaat dan volgens de memorie van toelichting om 'een afbeelding die een zodanig intiem seksueel karakter heeft dat deze door

18. Kamerstukken I/ 2018/19, 35080, nr. 3 (MvT), p. 4.

19. Advies OM d.d. 12 juni 2018, p. 3; Kamerstukken // 2018/19, 35080, nr. 3 (MvT), p. 18-19.

20. Kamerstukken // 2018/19, 35080, nr. 7 (nota n.a.v. het verslag), p. 9. ieder redelijk denkend mens als privé zal worden beschouwd'. ${ }^{21}$ Als voorbeeld wordt een (deels) ontbloot lichaam genoemd, of een afbeelding waar borsten, billen of geslachtsdelen prominent in beeld worden gebracht. Ook beeldmateriaal van iemand die - al dan niet (deels) ontkleed - seksuele handelingen verricht met zichzelf of een ander kan een seksuele aard hebben. ${ }^{22}$ Het begrip 'afbeelding' omvat 'alle vormen van beeldmateriaal, zoals foto's, videomateriaal en live streamingbeelden'.23

In het eerste lid onder a wordt strafbaar gesteld hij die 'opzettelijk en wederrechtelijk' een dergelijke afbeelding van iemand makkt. Over de wederrechtelijkheid als bestanddeel is de memorie van toelichting kort en duidelijk: 'van wederrechtelijkheid is sprake als een afbeelding van seksuele aard zonder medeweten of zonder toestemming van de afgebeelde is vervaardigd' ${ }^{24}$ Als gevolg van de formulering is geen opzet op de wederrechtelijkheid vereist.

Over openbaar maken meldt de memorie van toelichting dat hiermee wordt aangesloten bij het openbaar maken in artikel $139 \mathrm{~g} \mathrm{Sr}$ ('ter beschikking van een ander stellen' en 'aan een ander bekend maken'). Hieronder valt zowel het aan één persoon als aan meer personen bekend maken. ${ }^{25}$ Toch liet de minister in het midden of het enkele tonen van bijvoorbeeld een filmpje aan één persoon steeds zal gelden als openbaar maken. Dit kan, maar hoeft niet telkens het geval te zijn. De dader moet zich wenden tot (iemand in) het publiek met de wil om openbaar te maken, aldus de minister. ${ }^{26}$

Voor de delictsgedraging 'vervaardigen' van een afbeelding verwijst de memorie van toelichting naar het al langer bestaande artikel $139 \mathrm{f} \mathrm{Sr}$. Het behoeft geen betoog dat hieronder in de eerste plaats het maken van foto's en video's wordt verstaan. Ook het maken van screenshots is evident het vervaardigen van een afbeelding. In het kader van artikel 139f Sr heeft Rechtbank Gelderland in 2016 geoordeeld dat ook het live meekijken via een webcam kan gelden als het vervaardigen van een afbeelding. ${ }^{27}$ Deze interpretatie lijkt op het eerste gezicht nogal extensief, maar volgt wel een standpunt dat al geruime tijd in de wetsgeschiedenis wordt ingenomen. ${ }^{28}$

21. Kamerstukken I/ 2018/19, 35080, nr. 3 (MvT), p. 22.

22. Zie tevens Kamerstukken // 2018/19, 35080, nr. 7 (nota n.a.v. het verslag), p. 9.

23. Kamerstukken // 2018/19, 35080, nr. 3 (MvT), p. 22

24. Idem.

25. Kamerstukken // 2018/19, 35080, nr. 3 (MvT), p. 23

26. Kamerstukken // 2018/19, 35080, nr. 7 (nota n.a.v. het verslag), p. 11.

27. Rb. Gelderland 29 augustus 2016, ECLI:NL:RBGEL:2016:4801.

28. Onder het 'vervaardigen' van een afbeelding moet ook worden verstaan een 'eenmalige en tijdelijke beeldvorming, anders dan op het netvlies van de toeschouwer'. De minister oordeelde in 1970 ook dat 'het door middel van een gesloten televisiecircuit waarnemen van personen in kleed- en andere ruimtes onder de (...) strafbepaling valt indien voor het overige aan de delictsomschrijving is voldaan' (Kamerstukken II 1969/70, 9419, nr. 4, p. 7). In 2001 heeft de minister in het kader van art. 441b Sr nog herhaald dat het enkele meekijken via een webcam ook moet worden gekwalificeerd als het vervaardigen van een afbeelding (Kamerstukken // 2000/01, 27732, nr. 5, p. 12-13). 
Het eerste lid verbiedt onder b ook het beschikking hebben over een afbeelding van seksuele aard, voor zover iemand peet of redelijkermijs moet vermoeden dat die afbeelding opzettelijk en wederrechtelijk is vervaardigd. In deze formulering schuilen een opzet- en een schuldvariant. Voor het meten volstaat voorwaardelijk opzet. Redelijkermijs moeten vermoeden kan worden bewezen indien de verdachte aanmerkelijk onvoorzichtig handelde en bij enig nadenken wel had kunnen vermoeden dat de afbeelding wederrechtelijk is vervaardigd ${ }^{29}$ Het tweede lid onder a kent hetzelfde schuldverband.

Ten slotte verbiedt het tweede lid onder b het openbaar maken van een afbeelding van seksuele aard, terwijl men peet dat die openbaarmaking nadelig kan zijn voor die persoon. De Kamerstukken geven geen verdere duiding over dit schuldverband omdat deze formulering bij amendement is toegevoegd. ${ }^{30}$ Het moeilijk te bewijzen 'oogmerk om de afgebeelde persoon te benadelen' is vervangen door 'weten dat die openbaarmaking nadelig kan zijn'. Deze variant ziet op de situatie waar een afbeelding van seksuele aard op normale wijze tot stand is gekomen, maar de openbaarmaker ten minste voorwaardelijk opzet heeft op mogelijk nadelige gevolgen voor de afgebeelde persoon. Het is verleidelijk om aan te nemen dat de wetgever de situatie voor ogen heeft gehad waarin geen toestemming is gegeven door de afgebeelde persoon. Dat is echter - zoals hierna bij de knelpunten nog aan de orde komt - niet wat in de wettekst staat.

\section{Knelpunten}

Bij een nieuwe strafbepaling is het bijna onvermijdelijk dat op voorhand niet precies duidelijk is hoe de bepaling in de praktijk zal worden uitgelegd. Tegelijkertijd vereist artikel 7 EVRM dat een strafbepaling 'clearly defined in law' dient te zijn, waarbij zowel de wettekst als de rechtspraak duidelijkheid kunnen scheppen. ${ }^{31}$ Als niet aan deze eis is voldaan, is sprake van strijd met het in het legaliteitsbeginsel besloten liggende vereiste van lex certa. Strijd met dit bepaaldheidsgebod wordt in de rechtspraak zelden aangenomen, maar dat ontheft de wetgever niet van de verplichting om strafbepalingen zo duidelijk mogelijk te redigeren. ${ }^{32}$ Hierna zal in het

29. Kamerstukken I/ 2018/19, 35080, nr. 7 (nota n.a.v. het verslag), p. 10 Zie over de verhouding tussen weten en redelijkerwijs moeten vermoeden (in de context van witwassen): HR 16 juni 2015, ECLI:NL:HR: 2015:1660

30. Kamerstukken I/ 2018/19, 35080, nr. 21 (nader gewijzigd amendement van de leden Van Wijngaarden en Groothuizen ter vervanging van dat gedrukt onder nr. 14).

31. Zie o.a. EHRM 25 mei 1993, ECLI:CE:ECHR:1993:0525JUD001430788 (Kokkinakis/Griekenland), par. 52. Voorts ligt het bepaaldheidsgebod besloten in het legaliteitsbeginsel zoals neergelegd in art. $1 \mathrm{Sr}$.

32. Zo leverde zelfs het begrip 'zich onbehoorlijk gedragen' geen strijd op met het bepaaldheidsgebod (HR 2 april 1985, NJ 1985/796). De Hoge Raad overwoog dat de norm 'in zoverre is geconcretiseerd dat het gaat om gedrag op de stations en in de treinen' en dat wettelijke normen onvermijdelijk vervat zijn in min of meer vage termen, waarvan de bijzonder aandacht worden besteed aan een aantal knelpunten, namelijk de afbakening van de hiervoor besproken bestanddelen, het bereik van de bepaling en de keuze om geen klachtvereiste in te voeren. ${ }^{33}$

\subsection{Afbeelding?}

De nieuwe bepaling richt zich uitsluitend op afbeeldingen, zodat bijvoorbeeld een geschrift of geluidsfragment van seksuele aard evident buiten het bereik van artikel $139 \mathrm{~h} \mathrm{Sr}$ valt. ${ }^{34}$ Uit de wetsgeschiedenis volgt, zoals we hiervoor zagen, dat het begrip afbeelding 'alle vormen van beeldmateriaal' omvat, zoals foto's, videomateriaal en live streamingbeelden. Maar hoe zit het met bijvoorbeeld een deepfake - een zeer realistische ogende, met kunstmatige intelligentie gemaakte nepvideo? Met deze technologie worden al video's gemaakt die levensecht lijken, maar het niet zijn. ${ }^{35} \mathrm{Zo}$ is van voormalig nieuwslezeres Dionne Stax een nepseksvideo verspreid. ${ }^{36}$ Of stel dat iemand een alledaagse foto van een persoon zodanig bewerkt dat het lijkt dat die persoon naakt is, of betrokken bij iets seksueels. Naar de letter van de wet is dan een afbeelding van seksuele aard van die persoon vervaardigd. Toch is niet op voorhand duidelijk of de wetgever deze situatie wel of niet voor ogen heeft gehad. ${ }^{37}$ Dat is een gemiste kans, juist nu deepfakes een grote opmars maken. Gelet op de ratio van de strafbaarstelling mag worden aangenomen dat fotorealistische afbeeldingen wel onder artikel $139 \mathrm{~h} \mathrm{Sr}$ zullen vallen.

Maar hoe zit het met een bijzonder realistische tekening of schilderij waar iemand compromitterend op seksuele wijze is afgebeeld? Kan dit onder omstandigheden een afbeelding van seksuele aard zijn, en, zo ja, waar liggen dan de grenzen? Kan door zo'n tekening of schilderij het beschermde belang, de seksuele privacy, worden aangetast? Of kan dat enkel indien het levensecht audiovisueel materiaal betreft? De rechter die zich geconfronteerd ziet met een dergelijke tenlastelegging, zal zich moeten verlaten op grammaticale en teleologische interpretatie nu de wetsgeschiedenis hierover niet duidelijk is. Het zou wenselijk zijn geweest om hierover in de memorie van toelichting een heldere keuze te maken. Een naar ik

interpretatie en toepassing in de praktijk vorm moeten krijgen (onder verwijzing naar EHRM 26 april 1979, ECLI:CE:ECHR: 1979:0426JUD000653874 (The Sunday Times/Verenigd Koninkrijk), NJ 1980/146, par. 49

33. Zie voor een kritische beschouwing ook M.L.R. Goudsmit, 'Criminalising image-based sexual abuse: an analysis of the Dutch bill against "revenge pornography"', AA 2019, p. 442-447.

34. De wetsgeschiedenis zwijgt over die beperking. Het zou op zichzelf denkbaar zijn geweest om een formulering te kiezen die bijvoorbeeld ook audiofragmenten (zogenoemde voiceapps) zou omvatten.

35. Zo was medio 2019 zelfs een app verkrijgbaar, DeepNude genaamd, waarmee een foto van een geklede vrouw in enkele klikken in een naaktfoto kon worden veranderd (zie J. Duursma, 'Gevaarlijk echt, die nepvideo's. Door "deepfakes" kunnen we onze ogen en oren niet vertrouwen: waakzaamheid is geboden in de nieuwe schijnrealiteit', de Volkskrant 19 juli 2019, p. 19).

36. R. Kist, 'De deepfake rukt op in porno en politiek', NRC Handelsblad 7 oktober 2019

37. In geval van kinderpornografisch materiaal (art. 240b Sr) is dan sprake van een afbeelding waarbij de kennelijk minderjarige 'schijnbaar betrokken' is. Virtuele kinderporno is naderhand dan ook strafbaar geworden (Kamerstukken I/ 2001/02, 27745, nr. 6). 
meen voor de hand liggende uitleg, gelet op de ratio van de bepaling, is dat ook fotobewerkingen en deepfakes onder het bereik van artikel 139h $\mathrm{Sr}$ vallen, maar slechts voor zover een redelijk oordelend persoon zal menen dat het een authentieke afbeelding is.

\subsection{Seksuele aard?}

De seksuele aard van een afbeelding is in de memorie van toelichting omschreven als 'een zodanig intiem seksueel karakter dat deze door ieder redelijk denkend mens als privé zal worden beschouwd'. Zo zal een daadwerkelijke seksvideo zonder meer een afbeelding van seksuele aard zijn. Toch zijn ook bij dit bestanddeel afbakeningsproblemen voorzienbaar.

Het begrip 'seksueel' is - voor zover het niet ziet op daadwerkelijke seks - in hoge mate normatief geladen en daarmee subjectief. Zo lijkt het erop dat de memorie van toelichting afbeeldingen van het naakte lichaam zonder meer onder de seksuele privacy schaart. In het advies van de Raad van State werd bij wijze van voorbeeld een sauna genoemd, die weliswaar privé, maar toch niet seksueel mag worden genoemd. ${ }^{38}$ Ook in de literatuur is bezwaar gemaakt tegen het seksualiseren van naaktheid door dit wetsartikel. ${ }^{39}$ Toch blijkt uit de parlementaire behandeling dat de minister afbeeldingen van privésituaties die feitelijk niet seksueel zijn wel degelijk ziet als afbeeldingen van seksuele aard. Hij verwijst immers naar gluurwebsites en stiekem gemaakte opnames in 'sauna's, kleed- of doucheruimtes' en 'vrouwen bij wie stiekem onder de rok of jurk is gefilmd' (upskirts). ${ }^{40}$ Daarmee is de minister voorbijgegaan aan het advies van de Raad van State om het bereik van de strafbepaling en de toelichting met elkaar in overeenstemming te brengen.

Het is ook de vraag of de seksuele aard van een afbeelding puur op basis van de afbeelding zelf wordt beoordeeld, of dat ook naar de wijze van totstandkoming, de bedoeling van de verdachte of specifieke omstandigheden van het slachtoffer, zoals zijn of haar culturele achtergrond zal worden gekeken. ${ }^{41}$ In de jurisprudentie inzake kinderporno heeft de Hoge Raad immers overwogen dat ook een op zichzelf onschuldige afbeelding in het concrete geval een onmiskenbaar seksuele strekking kan hebben. ${ }^{42}$ Verder heeft het Amsterdamse hof geoordeeld dat video-opnames van hockeypupillen die zich na

38. Kamerstukken // 2018/19, 35080, nr. 4 (advies Afdeling advisering Raad van State en nader rapport), p. 3.

39. Goudsmit noemt het 'problematisch' om een naakt lichaam zonder meer seksueel te noemen. Zij werpt de vraag op of uit de wetsgeschiedenis dan ook moet worden afgeleid dat de minister een sauna 'een seksuele omgeving' vindt (M.L.R. Goudsmit, 'Criminalising image-based sexual abuse: an analysis of the Dutch bill against "revenge pornography"', AA 2019, p. 446).

40. Kamerstukken // 2018/19, 35080, nr. 3 (MvT), p. 4.

41. Goudsmit meent dat het begrip 'seksuele aard' nadere duiding behoeft en verwijst ter inspiratie naar art. 78 van de UK Sexual Offences Act 2013, waarin is vermeld: 'an activity is sexual if a reasonable person would consider that (a) (...) it is because of its nature sexual, or (b) because of its nature it may be sexual and because of its circumstances or the purpose of any person in relation to it (or both) it is sexual.'

42. HR 7 december 2010, ECLI:NL:HR:2010:BO6446. de training uitkleedden om te gaan douchen - gelet op de wijze van totstandkoming en het gedrag van de verdachte - kinderpornografisch waren. ${ }^{43}$

Bij deze lijn in de rechtspraak valt ten eerste de kanttekening te plaatsen dat de wijze van totstandkoming van een afbeelding zuiver bezien niet zoveel te maken heeft met een seksuele aard of gedraging. Ten tweede roept het meewegen van een subjectieve component als de intentie van de verdachte tal van nieuwe vragen op. De minister noemt onder meer upskirts als voorbeeld, maar kan dit ook gelden voor beelden van décolletés gemaakt op een zonnig terras, of voeten in teenslippers door voetfetisjisten, wanneer deze stiekem worden gemaakt? En kunnen de specifieke omstandigheden van het slachtoffer relevant zijn voor het oordeel van de rechter? Het openbaar ministerie veronderstelde in zijn advies dat een foto van een meisje in een te kleine bikini in de moslimgemeenschap mogelijk niet passend zou worden geacht, maar bij 'een blonde Hollandse vrouw' wel. ${ }^{44}$ Moet de rechter dan onderscheid maken op basis van de culturele achtergrond van de afgebeelde persoon? Vanuit het uitgangspunt van privacy is hier veel voor te zeggen, maar vanuit het perspectief van rechtszekerheid is dit buitengewoon onwenselijk. ${ }^{45}$

Kortom, het begrip 'seksuele aard' is een weinig vastomlijnd begrip. Enerzijds kan daardoor de seksuele privacy van personen wellicht effectiever worden beschermd, maar tegelijkertijd wordt zo wel een schemergebied gecreëerd ten aanzien van de reikwijdte van een strafbepaling. Het is dan ook aan de rechter om de grenzen te gaan bepalen binnen de context van de actuele sociaal-ethische norm.

\subsection{Openbaar maken?}

De verbodsbepalingen in het eerste lid zien - kort gezegd - op het stiekem vervaardigen van seksueel beeldmateriaal of het stiekem daarover beschikken. In het tweede lid staat het openbaar maken centraal, zelfs wanneer het (in de laatste variant) om vrijwillig tot stand gekomen materiaal gaat.

Ten aanzien van het openbaar maken zagen we hiervoor dat de ondergrens in de wetsgeschiedenis niet geheel duidelijk is aangegeven. De SGP-fractie vroeg de minister opheldering over het begrip 'openbaar maken'. ${ }^{46} \mathrm{De}$ minister antwoordde dat het enkele tonen van een afbeelding aan een groep omstanders in het algemeen

43. Het hof erkende dat de beelden niet expliciet seksueel waren, maar wees op de plaats waar gefilmd werd (kleedkamer), de wijze waarop dit gebeurde (stiekem) en oordeelde dat de opnamen gezien die wijze van tot stand komen strekten tot het opwekken van seksuele prikkeling. Bovendien leidde het hof dit af uit het gedrag van de verdachte (Hof Amsterdam 14 oktober 2015, ECLI:NL:GHAMS:2015:4209, r.o. 5.1.7-5.1.19).

44. Advies OM d.d. 12 juni 2018, p. 4.

45. Het OM acht dit ook onwenselijk en trekt een vergelijking met vermogensdelicten. Immers is bij diefstal van $€ 1.000$ voor het bewijs niet van belang of het slachtoffer dat geld wel of niet makkelijk kon missen. Hoewel dat juist is, is het voorbeeld minder gelukkig gekozen omdat privacy - anders dan eigendom - een contextgebonden recht is dat deels normatief wordt ingevuld.

46. Kamerstukken I/ 2018/19, 35080, nr. 5 (verslag), p. 12. 
voldoende zal zijn, en dat onder omstandigheden zelfs het tonen aan één persoon al zal kunnen gelden als openbaar maken. ${ }^{47}$ Daarbij heeft de minister aansluiting gezocht bij artikel $131 \mathrm{Sr}$ (opruiing) door te verwijzen naar het commentaar van Noyon Langemeijer Remmelink bij dat artikel. ${ }^{48} \mathrm{Bij}$ de beantwoording van de vragen van de SGP vat de minister het als volgt samen, daarbij NLR parafraserend: 'Onder de term «openbaar maken» in artikel $139 \mathrm{~h} \mathrm{Sr}$ valt het aan één of meer personen bekend maken. Dit houdt in dat de dader zich wendt tot het publiek of iemand in het publiek; de dader moet de wil gehad hebben om openbaar te maken.'

In de context van andere strafbepalingen, bijvoorbeeld het openbaar maken van staatsgeheimen (art. 98a Sr), is een andere uitleg gegeven aan 'openbaar maken'. Zo heeft Hof Den Haag geoordeeld dat geen sprake was van openbaar maken toen iemand per e-mail geheimen deelde met één respectievelijk twee personen. ${ }^{49}$ Het hof overwoog dat de intentie van de verzender was om de informatie uitsluitend met deze personen te delen. Daarbij had hij weliswaar de kans aanvaard dat anderen - zoals huisgenoten van de geadresseerden - kennis zouden nemen van die informatie, maar hij zou niet de kans hebben aanvaard dat die informatie in dusdanig brede kring van personen bekend zou worden dat die informatie in beginsel voor iedere belangstellende bereikbaar zou worden'. ${ }^{50}$ Daarmee legt het hof hier een aanmerkelijk andere maatstaf aan dan de minister met artikel 139h Sr kennelijk voor ogen heeft. Op soortgelijke wijze is geoordeeld over het bestanddeel 'in het openbaar' bij eenvoudige belediging (art. $266 \mathrm{Sr}$ ). Een brief waarin het college van burgemeester en wethouders werd beledigd, die enkel ter kennis van de raadsleden was gebracht, kon niet gelden als een belediging in het openbaar. ${ }^{51}$

De interpretatie van de minister dat het enkele tonen aan ten minste één persoon voldoende kan zijn, is vanuit het beschermde rechtsbelang verdedigbaar. Dat kan in geval van intiem seksueel materiaal immers al een forse inbreuk op de privacy opleveren. Toch is het spijtig dat de wetsgeschiedenis niet meer handvatten biedt om de grenzen van dit bestanddeel precies te bepalen.

\subsection{Wetenschap omtrent nadeligheid?}

Wanneer een afbeelding van seksuele aard vrijwillig tot stand is gekomen, kan het openbaar maken daarvan nog steeds een strafbaar feit opleveren, namelijk onder artikel $139 \mathrm{~h}$ lid $2 \mathrm{sub}$ b Sr. Daarvoor is vereist dat de openbaarmaker 'weet dat die openbaarmaking nadelig voor [de afgebeelde] persoon kan zijn'. Deze formulering van de wetgever geeft te denken. Zoals we hebben gezien was in het conceptvoorstel vereist dat de open-

47. Kamerstukken I/ 2018/19, 35080, nr. 7 (nota n.a.v. het verslag), p. 11 Zie ook Kamerstukken I/ 2018/19, 35080, nr. 3 (MvT), p. 23.

48. NLR, aant. 3 bij art. $131 \mathrm{Sr}$.

49. Hof Den Haag 1 maart 2007, ECLI:NL:GHSGR:2007:AZ9644

50. Zie ook NLR, aant. 2 bij art. 98a Sr: 'Het betekent dat de inlichting (enz.) voor ieder die uit zichzelf bekwaam is om het tot zich te laten doordringen zonder bijzonder onderzoek of moeite kenbaar wordt.'

51. HR 30 oktober 2001, ECLI:NL:HR:2001:AB3143. baarmaker het oogmerk had de afgebeelde persoon te benadelen. Vanwege de hoge eisen die aan het bewijs van oogmerk worden gesteld, is gekozen voor de huidige formulering. Die is echter hoogst ongelukkig, omdat er niet voor is gekozen het begrip 'wederrechtelijk' als bestanddeel toe te voegen.

Dat betekent dat het openbaar maken van een afbeelding van seksuele aard zelfs op uitdrukkelijk verzoek van de afgebeelde persoon nog strafbaar is, als de openbaarmaker bewust de aanmerkelijke kans aanvaardt dat die openbaarmaking nadelig voor die persoon kan zijn. Voorbeelden verzinnen is hachelijk, maar veronderstel dat een pornoproducent een film uitbrengt waarin een actrice haar debuut maakt. Gelet op de taboesfeer die ook in 2020 nog rond dit onderwerp heerst, kan deze openbaarmaking nadelig voor de actrice zijn. Het kan haar reputatie schaden, het kan problemen opleveren binnen haar familie of gemeenschap, et cetera. Bovendien kan moeilijk worden volgehouden dat de producent zich daarvan niet bewust was. Daarnaast valt te denken aan een stel dat samen vrijwillig en welbewust een seksvideo publiceert, wetende dat dit nadelig kan zijn. In deze voorbeelden zijn zowel de producent als het verliefde stel naar de letter van de wet strafbaar. Deze voorbeelden lijken wellicht wat gezocht, toch vloeit de strafbaarheid voort uit de huidige formulering van de nieuwe bepaling. De bepaling is daarmee uitermate breed geredigeerd. De wetgever zal dit vermoedelijk niet voor ogen zal hebben gehad.

De wetgever zou er goed aan hebben gedaan om de eis van wetenschap omtrent eventuele nadeligheid te schrappen, en simpelweg te volstaan met de formulering 'opzettelijk en wederrechtelijk openbaar maken'. Daarmee zou de strafbaarheid afhankelijk zijn van de instemming van de afgebeelde persoon. Dat past beter binnen de ratio van de wet, het persoonlijke karakter van privacy en de persoonlijke autonomie van de afgebeelde persoon.

\subsection{Geen klachtdelict}

Zowel in de consultatieronde als tijdens de parlementaire behandeling is aan de minister gevraagd waarom artikel $139 \mathrm{~h} \mathrm{Sr}$ niet de vorm van een klachtdelict zou krijgen. De adviescommissie strafrecht van de Orde van Advocaten wees erop dat sommige benadeelden vanwege het zeer persoonlijke karakter van seksueel beeldmateriaal wellicht helemaal geen vervolging wensen, om verdere aandacht voor het beeldmateriaal te voorkomen. ${ }^{52}$ De fractie van D66 vroeg tijdens de behandeling nogmaals aan de minister waarom niet voor een klachtvereiste was gekozen. ${ }^{53}$ De minister antwoordde dat klachtdelicten 'een uitzondering vormen' en dat de politie, wanneer een slachtoffer is opgespoord, met het slachtoffer de wenselijkheid van vervolging zal bespreken. ${ }^{54}$

52. Advies NOvA d.d. 11 juni 2018, p. 9

53. Kamerstukken I/ 2018/19, 35080, nr. 5 (verslag), p. 6.

54. Kamerstukken // 2018/19, 35080, nr. 7 (nota n.a.v. het verslag), p. 10. 
Dit antwoord overtuigt niet. Het komt problematisch voor dat juist bij zulk intiem materiaal openbare vervolging kan plaatsvinden, de afgebeelde persoon als getuige kan worden gehoord door de verdediging enzovoorts, terwijl deze persoon niet achter de vervolgingsbeslissing staat. De officier van justitie beslist zelfstandig op grond van het opportuniteitsbeginsel over vervolging, en daarbij kunnen bijvoorbeeld ook de ernst van het feit of algemene belangen, zoals de strijd tegen wraakporno, een rol spelen. Als de minister bedoeld heeft te zeggen dat de wens van de afgebeelde persoon doorslaggevend is, had het op zijn weg gelegen artikel $139 \mathrm{~h} \mathrm{Sr}$ aan te merken als een klachtdelict.

\section{Afronding}

Sinds 1 januari 2020 verbiedt artikel 139h Sr het stiekem maken van seksueel beeldmateriaal van een ander, het beschikken over en openbaar maken van zulk materiaal en het openbaar maken van beelden van seksuele aard wanneer men weet dat die openbaarmaking nadelig kan zijn. Tijdens de parlementaire behandeling riep vooral de omschrijving van het seksuele materiaal kritiek op. Deze omschrijving is in het wetsvoorstel gewijzigd, maar de kritiek is niet verstomd. Vervolgens is de bepaling bij amendement ingrijpend gewijzigd.

De precieze reikwijdte van de bestanddelen is nog niet uitgekristalliseerd, maar in dit artikel is alvast getracht de bedoeling van de wetgever uiteen te zetten en op enkele punten in het licht van bestaande rechtspraak te beschouwen. In het bijzonder is de uitleg van het centrale begrip 'afbeelding van seksuele aard' van belang. Dit bestanddeel is helder voor het gros van de gevallen, maar de precieze afbakening laat ondanks de parlementaire behandeling nog te wensen over. Een wezenlijk probleem doet zich voor bij de strafbaarstelling van artikel $139 \mathrm{~h}$ lid 2 sub b Sr, nu daar - vermoedelijk abusievelijk - niet het mederrechtelijk openbaar maken strafbaar is gesteld, maar openbaar maken terwijl men weet dat dit nadelig voor die persoon kan zijn. Dat omvat situaties waarin met toestemming seksueel materiaal wordt verspreid, terwijl men weet dat dit nadelig kan zijn. Deze variant van de strafbaarstelling staat op gespannen voet met het recht op seksuele zelfbeschikking. Naar de letter van de wet kan sprake zijn van strafbaarheid wanneer een stel samen een seksvideo publiceert, wetende dat dit nadelig kan zijn. De strafbaarstelling is in zoverre te breed en doet afbreuk aan de ratio van de bepaling en de keuze om zelf desgewenst de privacy deels op te geven. In het verlengde daarvan valt te betreuren dat het nieuwe verbod geen klachtdelict is. Nu kan immers ook vervolging plaatsvinden indien de afgebeelde persoon dit onwenselijk acht.

Het verbod op 'wraakporno', of beter gezegd misbruik van seksueel beeldmateriaal, zal in de rechtspraktijk vorm moeten krijgen. Als de reikwijdte van de bepaling goed wordt afgebakend, de eisen van het lex certa-begin- sel indachtig, kan het een nuttige toevoeging aan het Wetboek van Strafrecht vormen. 